\title{
Physico-Chemical Analysis of Culture Pond for Induced Pearl Production in Lamellidens marginalis
}

*Vijiyata Singh Rathour and Vijay Kumar Yadav

Department of Zoology, Bipin Bihari P.G. College, JHANSI (UP) INDIA

${ }^{*}$ Corresponding Author

E-mail : vijiyatarathour20@gmail.com

Received : 18.09.2020; Accepted : 22.10.2020

\section{ABSTRACT}

Bioassay experiments were carried out in order to evaluate values of physico-chemical parameters of the cultured pond water for induced pearl production in Lamellidens marginalis. The pond was located at Botanical garden of Bipin Bihari P.G. College, Jhansi. The parameters included for this study were Colour, Temperature, Transparency, $\mathrm{pH}, \mathrm{Free} \mathrm{CO}_{2}$, DO, Total Hardness, Calcium, Magnesium and Total Alkalinity of cultured pond water and to maintain them for the healthy growth of mussels during the whole culture period for obtaining designer pearls.

\begin{tabular}{lcc}
\hline Figures : 02 & References : 13 & Table : 01 \\
KEY WORDS : Designer pearls, Lamellidens & marginalis, Pearl culture, Physico-Chemical parameters. & \\
\hline
\end{tabular}

\section{Introduction}

Water's various Physico-chemical parameters may have an effect on its quality which directly or indirectly influences the flora and fauna of surroundings. Various kinds of pollutants enter water bodies and change the water quality.

Fresh water filter feeder mussels are commonly found in natural water bodies and they can be easily cultured in pond for the pearl culture purposes ${ }^{8}$. Water quality of pond may affect the size and health of mussels, survivality of mussels and pearl lusture. For quality production of pearl, mussels were cultured in pond under observed water condition. Many newly pearl farmers do not know the ideal range of water parameters and face many problems during pearl farming. Thus successful pond management requires a deep knowledge of water quality parameters. Therefore if they are properly guided and made aware about water quality management practices they get maximum yield of production ${ }^{1}$. The role of various factors such as Odor, Colour, Temperature, Turbidity, Transparency, pH, Calcium, Magnesium, Total hardness, and Total alkanity can't be ignored for the better and healthy aquatic environment and for the maximum survivality of pearl mussels and good quality lustured pearl.

Present study was conducted to evaluate the good growth and quality pearls during the culture period of Lamellidens marginalis.

\section{Material and Method}

The study was carried out from July 2016 to June 2017 in Botanical garden of Bipin Bihari P.G. College,
Jhansi. Water samples were collected monthly during morning hours throughout the culture period. For physicochemical analysis, water samples were collected in air tight sterile plastic bottles and analysis was done in departmental laboratory. For each sampling event colour, transparency, temperature, $\mathrm{pH}$ and dissolved oxygen (DO) were tested at the sampling site while total alkalinity, total hardness, calcium (Ca), magnesium $(\mathrm{Mg})$, were analyzed in the laboratory in accordance with the methods $^{3}$. The temperature were analyzed by Thermometer, $\mathrm{pH}$ were analyzed by Digital $\mathrm{pH}$ meter, Transparency were analyzed by sechhi disc, DO were analyzed by using standard Winkler method by titration, Alkalinity were analyzed by titration method, Calcium were analyzed by titration method, Total hardness were analyzed by using EDTA complex metric by titration method $^{11}$.

Fresh water mussel Lamellidens marginalis were collected from Knot-Ghat site of Betwa River of Uttar Pradesh. Mussels were collected from sediment's surface of the river with the help of local fishermen. The collected mussels were kept in a container along with natural water and transferred to the laboratory for acclimatization for 5 days. After 5 days the mussels were washed with tap water and kept in trays for relaxing. After morphometric analysis and insertion of nucleus, the mussels were tagged and transfered to the culture pond.

\section{Result and Discussion}

During the one year culture period, the physicochemical parameters of the culture pond were analyzed (Table-1). 


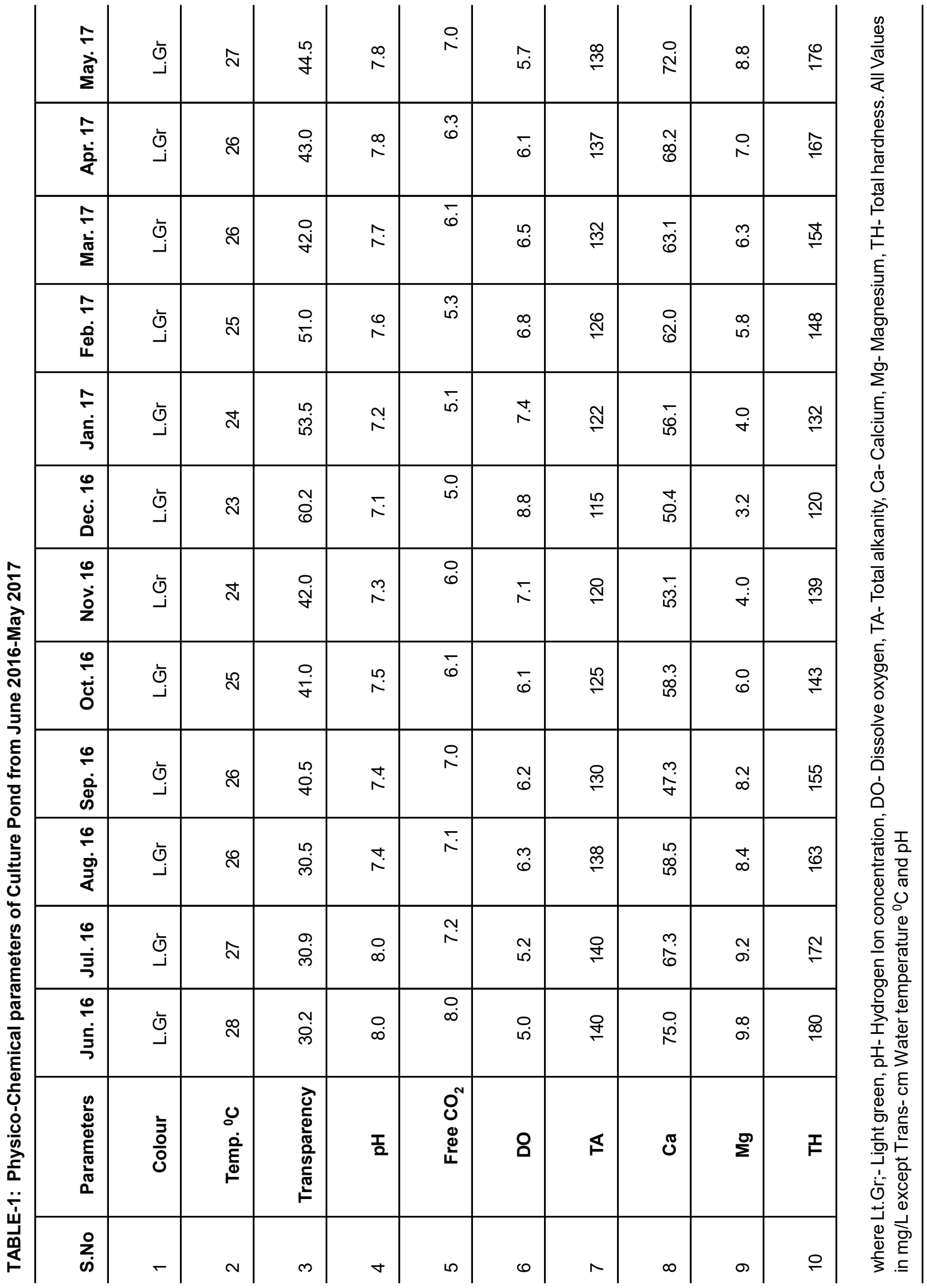




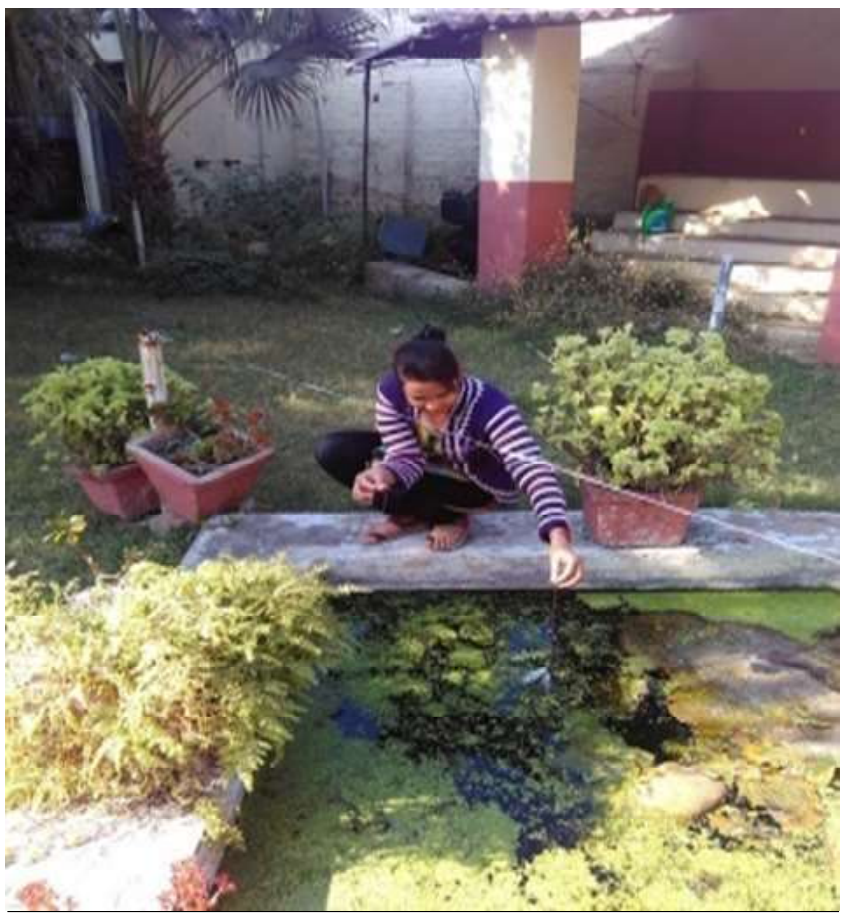

Fig. 1 : Pond management

The obtained results of physico-chemical parameters were compared with Standard prescribed under $\mathrm{APHA}^{3}$. The colour of pond water was light green during the whole research period as the pond is rich in plankton population ${ }^{6}$.

Temperature plays a vital role in Nacre secretion and deposition activities of the mussels ${ }^{13}$. In the present study the range of temperature was observed between $23^{\circ} \mathrm{C}$ to $28^{\circ} \mathrm{C}$. The water temperature was recorded minimum $\left(23^{\circ} \mathrm{C}\right)$ in December 2016 and maximum $\left(28^{\circ} \mathrm{C}\right)$ in June 2016.

Transparency is an important biological parameter; it helps in the production of plankton. In the present study the range of transparency was observed between $30.2 \mathrm{~cm}$ to $60.2 \mathrm{~cm}$.

$\mathrm{pH}$ is a term used to express the intensity of the acid or alkaline condition of a water which influences aquatic production ${ }^{6}$. The $\mathrm{pH}$ values of culture pond water ranged between 7.1 to 8.0 which reports the alkaline condition.

Dissolved Oxygen plays a vital role in the growth, survival, behavior and physiology of aquatic organism ${ }^{12}$. The optimum concentration of DO in pond waters was 6 to $9 \mathrm{mg} / \mathrm{L}^{5}$. In the present study the values of DO were in

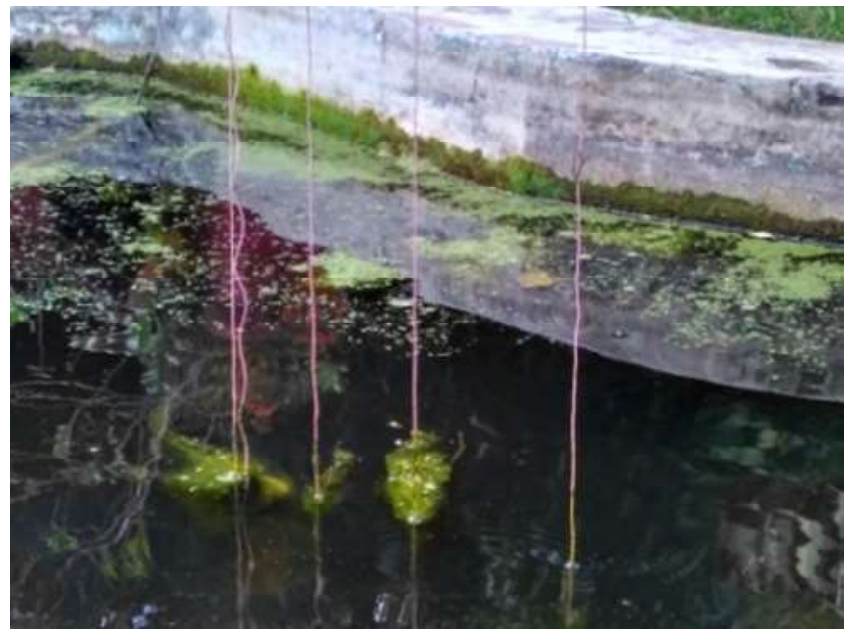

Fig. 2 : Hanging Mussel culture

the range of $5.0 \mathrm{mg} / \mathrm{l}$ to $8.8 \mathrm{mg} / \mathrm{l}$ in pond water.

The Total alkalinity was recorded in the range between $120 \mathrm{mg} / \mathrm{l}$ to $140 \mathrm{mg} / \mathrm{l}$ in the present study.

Hardness of water generally depends upon the quantity of calcium or magnesium salts or both ${ }^{10}$. The Total Hardness values of culture pond water were observed between $120 \mathrm{mg} / \mathrm{L}$ to $180 \mathrm{mg} / \mathrm{L}$.

Calcium is the most abundant substances of the natural waters. Calcium is an important essential factor for the shell growth of mussels and also an important constituent part of pearl. The calcium concentration in the present study ranged between $50.4 \mathrm{mg} / \mathrm{L}-75.0 \mathrm{mg} / \mathrm{L}$

Generally magnesium content is lower than calcium ions in natural water but due to addition of animal manures and other wastes in water bodies its concentration increases. It is the most abundant elements in nature which is essential for plankton's growth since it is an essential constituent of chlorophyll ${ }^{10}$. The magnesium concentration in the present study ranged between $3.2 \mathrm{mg} / \mathrm{l}$ to $9.8 \mathrm{mg} / \mathrm{l}$ of the culture pond.

\section{Conclusion}

The results obtained in the present study indicates that the culture pond is suitable for culturing of fresh water mussel Lamellidens marginalis but periodic assessment of the water body is also recommended throughout the culture period. The values of different parameters are in accordance with standard values and other research works. Hence, the present study has great potential in promoting pearl culture farming in Bundelkhand region for its socio-economic development.

\section{References}

1. Adoni AD. Work book on limnology, Pratibha Publications Sagar (M.P.). 1985; p 199-206.

2. APHA (American Public Health Association). Standard methods for the examination of water and wastewater. 19th edition. American Public Health Association, American Water Works Association, and Water Environment 
Federation, Washington, DC. 1995.

3. APHA. Standard method for the estimation of water and waste water, 21st Ed., Washington DC.2005.

4. Bhatnagar Anita, Devi P. International Journal of Environmental Sciences. 2013; 3 (6) : ISSN: 0976-4402, 19802009p.

5. Boyd CE. Water Quality Management for Pond Fish Culture., Elsevier Science Publishing Company., New York. 1982.

6. Hora SL, Pillay TVR. Hand book on fish culture in India-Pacific region, FAO Fish Biol.Tech. $1962 ; 14$ : 204.

7. Janaki Ram K. Fresh water pearl culture in India. Aquabyte section. 1997.

8. Misra G, Mukhapadhyay PK. Aquaculture asia Magzine, Research and Farming Techniques. 2008; $32-33$.

9. NN, Susithra R. Journal of Pharmacy and biological sciences ISSN: 2319-7676. 2016; 11 (1) : 36-42.

10. Rath P, Bhatta D, Sahoo BN, Panda UC. Multivariate statistical approach to study physico-chemical characteristics in Nandira Brahmani River, Angul-Talcher Belt. Orissa, India. Poll. Res. 2000; 19 (4): $701-710$.

11. Razda Sheikh, Suchitra Banerjee, Rajendra Chauhan, Ravi Prasad. Evaluation of physico-chemical parameters of fish culture pond water in Shri Ganeshan fish farm at Hoshangabad, Madhya pradesh, India. Dama International.TFR. V. 2017; 6(3): 2319-4758.

12. Solis NB. The Biology and Culture of Penaeus monodon Department Paper, SEAFDEC Aquaculture Department, Tigbouan, Boilo Philippines. 1998; 3 - 36.

13. Suryawanshi AV, Kulkarni AN. Nacre Secretion with Respect to Temperature in Fresh Water Bivalvel Parreysia corrugata from Nanded Region, Maharashtra. International journal of pure and applied biosciences. 2015; 3 (4): 33-36. 